\title{
THE EUROPEAN ENERGY POLICY - A FRAMEWORK FOR DECREASING THE GAP BETWEEN MEMBER STATES. IS THE ENERGY MARKET LIBERALIZATION A SUSTAINABLE APPROACH OR AN ONGOING RISK?
}

\author{
Andrada Văsii \\ National University of Political Studies and Public Administration \\ Bucharest, Romania \\ andrada.vasii@yahoo.com
}

\begin{abstract}
Energy independence was a long-time dream of European Member States, thus numerous regulations and actions were designed specific for its implementation. In a society characterized by constant evolution, energy independence is regarded as a proof of the existence of coherent supranational strategies, but also as a necessary effort that is to be unravelled at national level. Unlike the first actions in the energy sector, the current market is the expression of a competitive space that has adapted an approach depending upon efficiency and sustainability.

In this paper, I present, using a macro-level approach, the transformations of the European energy market and the challenges that arise. I examine both the actions that lead to the liberalization efforts, as well as the disparities that characterize the Member States involved in this process. Therefore, I question the process of liberalization of the energy market as being a straight-forward one and I investigate the variables (such as types of energy and national energy strategies) that directly influence this process.

This aim of this paper is to offer insights, using both a quantitative and a qualitative approach, in the way in which the liberalization process ought to
\end{abstract}


occur, and elaborate on the country-specific factors that affect it, making liberalization a process characterized by vulnerabilities.

\section{Keywords}

Energy, European Energy Policy, framework, market liberalization, vulnerability

\section{INTRODUCTION}

The energy market in the European Union, and its way of functioning, has been widely discussed among scholars. The liberalization of the market is presented as the next step in the effort of strengthening the European energy market, an effort that must be supported by activities and policies implemented at national level. Starting with the first steps (creating an Union meant to ensure stability), the involved states have been subjected to several changes, development in terms of legislation and internal market design, in order for them to fall in line with the European strategies. Even so, the public policies implemented at national level, cannot, and must not be interpreted from a single point of view: were they necessary for the liberalization of the energy market? The question must be accompanied by an in-depth analysis of its implications: what were the changes in terms of economic, social and technological factors for each Member State? The urgent need for a coherent energy policy can be understood when investigating the disparities amongst the Member State, disparities such as number of operators on the market, economic potential, level of infrastructure, as well as intake of legislative changes to the national framework.

In this paper, the focus is not on the micro-accomplishments of the European Energy Policy, but on the way in which a European energy framework decreases the gap between Member States (or if not the case, why it fails to do so). In the first part of the paper, I will present and analyse the measures that enforced liberalization, explaining what disparities are present at market level. In addition, using both a qualitative and a quantitative approach, I will demonstrate that the European Union dependence on imported energy sources was countered along the way by designing a comprehensive strategy aimed to 
stimulate the emergence of an internal market. In the second part of the paper, I will investigate the activities that have encouraged states to increase their intake in terms of efficiency and productivity. The paper finalizes with the answer to the question concerning to what extent can the liberalization process be considered an in-depth one, as long as several disparities still arise at national level.

\section{ENERGY MARKET LIBERALIZATION. AN INCERMENTAL APPROACH}

The liberalization of the energy and gas market in the Europe Union is an ongoing process, carried out through specific efforts and promoted with the help of documents such as Directives, Action Plans, Strategies and, not the least, domestic measures taken by the Member States.

Even though not declared as steps towards attaining a liberalized energy market, in 1988 the Commission of the European Communities drafted a working document called The Internal Energy Market, document that characterized the existing energy market as follows (The Internal Energy Market 1988, 4-5):

1. A diverse market, in terms of end-users (consumers) and delivered products

2. The end-uses of energy products is not similar in all Member States

3. The energy operators differ (in size and rights)

4. Behaviour (as well as taxation procedures) are not the same for each Member State

The previous mentioned factors demonstrate that in 1988 the energy market was far from suitable to be liberalized and to allow Member States to decide (and negotiate) with suppliers and operators. Moreover, transnational transmission systems could not have been regulated easily given the fact that taxation was implemented by each Member State in a different manner. Amongst the proposed measure for decreasing disparities, economic and social cohesion were starting points in the mentioned document; thus, Structural Funds were 
considered to be an important element when dealing with these problems (The Internal Energy Market 1988, article 31).

In the following years, the first steps in grasping a liberalized market have been taken in 1996 (for the electricity sector) and in 1998 (for the gas sector) with the help of special tailored Directives.

Directive 96/92 drafted in 1996 set the grounds for common rules for the internal electricity market. The declared purpose of this document was to provide a set of common rules in terms of distribution, generation and transmission of electricity, by tackling problems such as access to the energy market and procedures designed for the operation of systems (Directive 96, article 1). The variables considered in the scope of the Directive are marks of a complex strategy devised both for micro level actions (access to the market), as well as for macro level actions (distribution and transmission grids and infrastructure). For a better organization of the energy sector, the Directive proposed several actions that could have been taken by Member States, actions as following:

"Member States shall ensure, on the basis of their institutional organization and with due regard for the principle of subsidiarity, that, [...] electricity undertakings are operated in accordance with the principles of this Directive, with a view to achieving a competitive market in electricity, and shall not discriminate between these undertakings as regards either rights or obligations." (Directive 96, article 3).

Even though the purpose was to ensure the development of a competitive common energy market, the national specific, with its existing variables (the institutional organization), was being taken into consideration.

Furthermore, the Directive brings into force the obligations of the transmission systems operators, making them responsible for an overview of the system:

"The transmission system operator or any other competent authority designated by the Member State concerned shall draw up and publish under State supervision, at least every two years, a regular estimate of the generating and transmission capacity which is likely to be connected to the system, of the need for interconnectors with other systems, of potential transmission capacity and of the demand for electricity. The estimate shall cover a period defined by each Member State." (Directive 96, article $6(2)$ ). 
Whilst similar to an evaluation, these measures would have needed an external supervisor, an organization which could have overseen the faultlessness of the provided data. In addition, for newer Member States, the need for a good practice exchange (or manuals) would have been compelling, so that the reports met the expected conditions.

Similar to the Energy Directive, the Gas Directive aimed to set grounds for a competitive internal market for natural gas, by setting the distribution, storage of natural gas and supply as points of interest (Directive 98 1998). Unlike the Energy Directive, the Gas Directive was more direct in regards to long term plans, namely the storage objectives. The concern for stable development in the natural gas sector is visible throughout the document, thus empowering the Member States to take appropriate actions in attaining these objectives:

"3. Member States shall ensure that the reasons for any refusal to grant an authorization are objective and non-discriminatory and are given to the applicant. Reasons for such refusals shall be forwarded to the Commission for information. Member States shall establish a procedure enabling the applicant to appeal against such refusals.

4. for the development of newly supplied areas and efficient operation generally, [...], Member States may decline to grant further authorization to build and operate distribution pipeline systems in any particular area once such pipeline systems have been or are proposed to be built in that area and if existing or proposed capacity is not saturated." (Directive 98, article 4(3), 4(4)).

Even though the European gas market was seen as a complex, interdependent system, the national specific was not overseen. The pillars for a stable development seem to have been both national decisions in accordance with the specific of the gas market (accepting or refusing a new supplier), as well as the control exerted by the Commission (constant informing of the status of rejected applicants).

A further step in obtaining a liberalized energy market has been the Directive 2003/54, a document designed to reinforce the common rules for the internal European electricity market. Given the disparities among states, the Directive made sure that fair service was to be provided to all European consumers; thus, all households consumers, and, if needed, small enterprises, ought to have had access to universal service, supplied with electricity characterized by a specific 
quality (Directive 2003, article 3). In terms of authorization power, Member States were allowed to set criteria that would encourage the construction of new capacity providers on their territory, criteria that may have encompassed:

"a) the safety and security of the electricity system, installations and associated equipment;

b) protection of public health and safety;

c) protection of the environment;

d) land use and siting;

e) use of public ground;

f) energy efficiency;

g) the nature of primary sources" (Directive 2003, article 5).

The prior mentioned criteria represent a step forward for the manner in which an efficient market was understood, because there could be observed a shift in focus - the appearance of energy efficiency and the question concerning the nature of primary sources as variables in the decision making process. In order to ensure the efficiency of the proposed new regulations, the Directive mentioned the rules that were to be applied to regulatory authorities. Hence, Member States were allowed to appoint one (or more) regulatory authorities, independent actors, which, in the long run, would ensure of the efficient functioning of the market (Directive 2003, article 23(1)).

In the following years, the liberalization framework has been strengthened through the help of the Treaty of Lisbon in 2007. The Treaty mentions that shared competences are to be developed between Member States and the European Union in several areas, including energy and trans-European networks (Treaty of Lisbon 2007, article 2c). Moreover, similar to risk case scenarios, the role of the European actors seems to be broadened:

"In Article 100, paragraph 1 shall be replaced by the following:

'1. Without prejudice to any other procedures provided for in the Treaties, the Council, on a proposal from the Commission, may decide, in a spirit of solidarity between Member States, upon the measures appropriate to the economic situation, in particular if severe difficulties arise in the supply of certain products, notably in the area of energy.' (Treaty of Lisbon 2007, 72). 
Effective measures can be taken the data provided suffices the need for information.

This is why the reports on regular estimates that were established in the Energy Directive could represent an important basis for strategic decisions in case of difficulties in distribution. Moreover, the Council was given decision power, action that eventually leads to a containment of possible threats to other states in case of scarce resources in the energy field. Moreover, the Treaty of Lisbon can be considered a blueprint for the development of the Energy union, because it depicts its evolution as a constant effort of striving to improve and preserve the environment as well as the internal market (Treaty of Lisbon, article 176a). In order to do so, activities such as ensuring the security of energy supply in the European Union, promoting the interconnection of energy networks, ensuring the proper functioning of the energy market, and advocating for energy saving and energy efficiency, as well as aiming to develop and use new forms of renewable energy, have been presented in the Treaty as mandatory (Treaty of Lisbon, article 176a).

The aforementioned conditions made it possible for the energy market to become more and more competitive (by using and developing new forms of renewable energy), and, in the same time, focused on the end-buyer (having a proper functioning market, means that regulatory mechanisms exists, and that the prices as well as the services provided are in the best interest of the buyer/consumer). 2016 represented another milestone in the process of establishing an in-depth, fully functioning, liberalized energy market all over the European Union. The document Clean Energy For All Europeans reinforced the idea that the Energy Union represents an important part a sustainable transition towards a low carbon economy (Clean Energy For All Europeans 2016, 3). In addition, it delineates the vulnerable consumer, as well as the energy poor one, as important actors in the process of ensuring access to clean and competitive energy (Clean Energy For All Europeans 2016, 3). Similar with the previous Directives in the field, the micro-level, particularly the consumers, are of great significance when outlining comprehensive energy strategies. A shift in paradigm can be observed in the case of the three goals established as priorities:

"Putting energy efficiency first 
Achieving global leadership in renewable energies

Providing a fair deal for consumers" (Clean Energy For All Europeans 2016, 3).

The aforementioned objectives can be regarded as the expression of an interconnected market, ready for the fine print of the process. The actions implied in the course of attaining these objectives are different from the steps recommended in the first Directives; specifically, there can be observed a shift from the interest in developing a sustainable infrastructure towards claiming leadership (and know-how) in the energy field, as well as implementing reliable and stable quotas for consumers.

Table no 1. Electricity prices in the European Union / ratio to the prices other countries

\begin{tabular}{|l|l|l|l|l|}
\hline Year & USA & China & Turkey & Russia \\
\hline 2012 & 2.2 & 1.1 & 0.9 & 2.1 \\
\hline 2013 & 1.9 & 1.1 & 1.0 & 2.2 \\
\hline 2014 & 1.3 & 1.1 & 1.1 & 2.6 \\
\hline 2015 & 1.7 & 1.0 & 1.0 & 3.5 \\
\hline
\end{tabular}

Source: Energy prices and costs in Europe 2015, p. 10

Out of its biggest partners on the energy market, the prices of electricity in Europe have encountered a valuable advancement in relation to the prices in USA (if in 2012 in Europe prices were 2.2 times bigger than in USA, in 2015 there can be seen a decrease of 0.5 points of ratio) and with Russia (dissimilar to the case of the USA, from 2012 to 2015 there has been an increase of 1.4 points of ratio). One possible explanation for these modifications could be the diverse nature of the energy production infrastructure in Europe (gas, coal, green energy). 
Table no 2. Electricity prices for domestic consumers in the European Union (excluding levies and taxes)/ unit of measurement - euro/kilowatt - hour

\begin{tabular}{|l|l|l|l|l|l|l|l|}
\hline Country & $\begin{array}{l}2013- \\
1^{\text {st }} \\
\text { semeste } \\
\mathrm{r}\end{array}$ & $\begin{array}{l}2013- \\
2^{\text {nd }} \\
\text { semeste } \\
\mathrm{r}\end{array}$ & $\begin{array}{l}2014- \\
1^{\text {st }} \\
\text { semeste } \\
\mathrm{r}\end{array}$ & $\begin{array}{l}2014- \\
2^{\text {nd }} \\
\text { semeste } \\
\mathrm{r}\end{array}$ & $\begin{array}{l}2015- \\
1^{\text {st }} \\
\text { semeste } \\
\mathrm{r}\end{array}$ & $\begin{array}{l}2015- \\
2^{\text {nd }} \\
\text { semeste } \\
\mathrm{r}\end{array}$ & $\begin{array}{l}2016- \\
1^{\text {st }} \\
\text { semeste } \\
\mathrm{r}\end{array}$ \\
\hline Bulgaria & 0.0771 & 0.0735 & 0.0689 & 0.0746 & 0.0785 & 0.0798 & 0.0797 \\
\hline France & 0.1051 & 0.1105 & 0.1064 & 0.1164 & 0.1111 & 0.1113 & 0.1087 \\
\hline $\begin{array}{l}\text { German } \\
\mathrm{y}\end{array}$ & 0.1493 & 0.1489 & 0.1435 & 0.1440 & 0.1431 & 0.1427 & 0.1388 \\
\hline $\begin{array}{l}\text { Hungar } \\
\mathrm{y}\end{array}$ & 0.1061 & 0.1019 & 0.0946 & 0.0902 & 0.0887 & 0.0902 & 0.0877 \\
\hline $\begin{array}{l}\text { Poland } \\
\text { Romani }\end{array}$ & 0.1155 & 0.1121 & 0.1107 & 0.1097 & 0.1125 & 0.1105 & 0.1037 \\
\hline $\begin{array}{l}\text { a Union } \\
\text { a }\end{array}$ & 0.1368 & 0.1386 & 0.1373 & 0.1397 & 0.1402 & 0.1419 & 0.1353 \\
\hline Spain & 0.1752 & 0.1787 & 0.1702 & 0.1861 & 0.1815 & 0.1864 & 0.1718 \\
\hline
\end{tabular}

Source: EUROSTAT

We can see that the disparities between Member States are still present, especially in the prices paid by domestic consumers for electricity. These disparities can be explained by taking into consideration specific attributes for each country; for example, energy production in countries that do not have a well prepared infrastructure (such as Bulgaria and Romania) must acquire energy at high rate prices. Moreover, the number of suppliers on the market may 
be another explanation for the diverse prices attained at European level (the more suppliers, the lower the prices). In 2016, Romania, Bulgaria, France, Hungary and Poland paid below the average of the European Union, whereas consumers from Germany and Spain paid above the average prices. Even though the average prices decreased from the first semester of 2013 with 0.0015 in 2016, three Member States are characterized by an increase in prices, as follows: Bulgaria (plus 0.0026), France (plus 0.0036), and Romania (plus 0.0024), making the liberalization process a complex one, in regards to the trends in prices at European level.

In accordance with the difference between Member States, in the same year a Directive of the European Parliament and of the Council has been presented in order to amend the Directive 2012/27/EU on the subject of energy efficiency. The end-consumer, more exactly the vulnerable one, was at the centre of this document, paper that states:

"Improvements to the energy efficiency of buildings should benefit in particular consumers affected by energy poverty. Member States can already require obligated parties to include social aims in energy saving measures, in relation to energy poverty, and this possibility should now be extended to alternative measures and transformed into an obligation while leaving full flexibility to Member States with regard to the size, scope and content of such measures [...]" (Directive of the European Parliament and of the Council 2016, article 12).

This time, urban planning and alternative actions became pillars for a better energy market, a market that can be regulated by the Member State as long as it falls in line with the European proposed measures. Although the vulnerable consumer has not been characterized in this document with specific variables (for example, income) this can be explained when considering the fact that the average income differs from state to state, making it impossible for the Parliament to establish a fair profile for this type of consumer. 


\section{STRATEGIC APPROACHES. ENERGY EFFICIENCY AND LONGTERM PLANS}

Taking into consideration the fact that each Member State has its own unique way of dealing with measures that concern the energy policy, it suffices to state that there exists an urgent need for a systematic approach in terms of strategies that are to be implemented at national level.

A first step in tackling the energy efficiency has been the Action Plan published in 2006, an initiative that has set the basis for a more efficient market, as well as encouraged interested actors from the energy field to change their behaviour. In doing so, six measures have been proposed in the Action Plan, as follows: improving energy transformation, improving energy performance, limiting the costs linked to transport, adapting international partnerships, changing behaviour, as well as a closer look at the financing, incentives and fares aspects (European Commission, 2006). In terms of energy transformation, the document proposes a strategy composed of mixed actions such as implementing good practices for suppliers, as well as for distributors of energy, and developing energy efficiency requirements for facilities that operate with less than 20 megawatts of power (European Commission, 2006). As depicted, these measures were designed to reshape the business sector, making it competitive. In doing so, extra measures such as evaluations of the current distribution corridors and existing infrastructure were needed so that the proposed good practices could be implemented at both micro and macro level.

The improvement of the energy performance has been understood as a need for both a consumer-focused system and standards for appliances (European Commission, 2006). Whilst the first implied that energy performance could be evaluated by consumers, the latter meant designing standards in order to attain the improvement of the energy yield for 14 groups of products (European Commission, 2006). Moreover, heat loss represented a point of interest at that time (European Commission, 2006). Unlike the energy transformation article, the measures proposed in the field of energy performance were designed both for the business sector, as well as for the consumer, leading to a more educated 
actor, hence empowering the consumer with skills that enable him to make right decisions.

On the infrastructure level, the document enforces a new perspective, one that promotes cleaner alternative transport for energy, as well as further development in the Urban Planning throughout cities around the European Union (European Commission, 2006). Dissimilar with the previous actions, the one concerning infrastructure bolsters the linkage of two pillars - urban planning and transport, setting the prerogatives for further development. Still, the differences in terms of innovation capacity, available technology and existing funds for this measure in all the European cities lead to different timeframes of implementation. In close relation with the prior measure, the action which strives to limit the costs linked to transport, key performance indicators such as cleaner alternative transport and reducing the polluting car emissions have been established (European Commission, 2006).

The following two areas proposed for improvement, incentives and financing, as well as changing the behaviour, were tailored specific for the micro-level, as an incentive for this sector. Specifically, the financing aspect was designed for the banking sector which would have been a promoter for medium enterprises, as well as large businesses that provided energy efficiency solutions, whereas the changing behaviour consisted of a strategy aimed to educate increase awareness of the consumer (European Commission, 2006). From the above mentioned consideration, an educated consumer appears to be an objective for the strategy that aims to establish a more efficient way of consuming and producing energy. On the other hand, each consumer abides its country regulation, as well as the quotas practiced by the suppliers in his area. This is why, when dealing with the education of the consumer, the diversity of the European energy markets must be considered a starting point for further analysis in the communication strategies. In Romania, for example, the Regulation no. 69/2009 concerning the Regulation of electric energy labelling was specifically designed towards educating Romanian consumers; its purpose was to inform the consumer in terms of energy production, as well as its impact on the environment (ANRE, 2009). 
The last measure, the development of international partnerships pin points trade policies, agreements and treaties as key performance indicators for an in-depth usage of technologies and techniques in the field (European Commission, 2006). Moreover, stable partnerships set the grounds for a functional energy market, one that can tackle ongoing risks, such as scarce internal resources, with the help of outside actors (other states with the capacity of sustaining the renewable energy consumption at fair prices; for example, Norway).

In 2009, the both the European Parliament and the Council of Europe have drafted a Directive with the purpose of promoting and encouraging the use of renewable energy sources. In this document, it is stated the fact that there is a need for transparent and clear criteria, criteria that are to be used when calculating the energy obtained from renewable sources (European Parliament 2009, 11). Moreover, the same document suggests that new forms of energy should be taken into consideration as renewable ones, as follows: salinity gradients, ocean thermal energy gradients, tides, marine currents and others (European Parliament 2009, 11). Extending the criteria for new types of energy sources means encouraging more Member States to develop, on the long run, coherent action plans for efficient management. On the other hand, not all states will have this advantage, because geographical factors such as climate and location will have a big impact; for example, states as the Czech Republic or Austria do not have marine potential, nor one that resides from ocean sources. This problem seems to be settled in the same document, given the fact that a new form of energy, namely biogas installations, is suggested as a point of interest for further development (European Parliament 2009, 12). By using this type of installations, agricultural materials become an important part in the renewable energy strategy (European Parliament 2009, 12). The latter stated approach means that a strategy for renewable energy cannot, and must not, be drafted without an ex-ante evaluation of the agricultural sector's capacity of sustaining such approaches. Thus, joint actions from both sectors would enable a coherent development of infrastructure, as well as establish a set of good practices for the micro-management of facilities (for both fields: agricultural and energy).

In terms of national targets, the document establishes for the year 2020 a $10 \%$ share in transport of energy obtained from renewable sources, as well as a $20 \%$ 
share for the same type of energy used in consumption (European Parliament 2009 , 13). Even though this percentage can be attained over time through incremental measures, the differences in terms of technological capacity, as well as innovation factors, between Member States could lead to a failure of such desiderates in certain states. For example, in Romania, in 2015, the electric energy delivered throughout the year was characterized as follows: $13.68 \%$ gas, $27.36 \%$ hydropower energy, $26.89 \%$ coal, $2.43 \%$ solar energy, $11.03 \%$ wind energy, $0.72 \%$ biomass, $17.83 \%$ nuclear energy and $0.06 \%$ oil fuel (ANRE, 2016); whereas in 2009 the energy market had a different aspect, as follows: $11 \%$ gas, $37 \%$ solid fuels, $2 \%$ liquid fuel, 29\% hydropower energy, 21\% nuclear energy (ANRE, 2009). Analysing the prior mentioned data, we can observe an increased tendency towards delivering solar energy, with $+2.43 \%$ in seven years, as well as an increase of $+11.03 \%$ in wind energy.

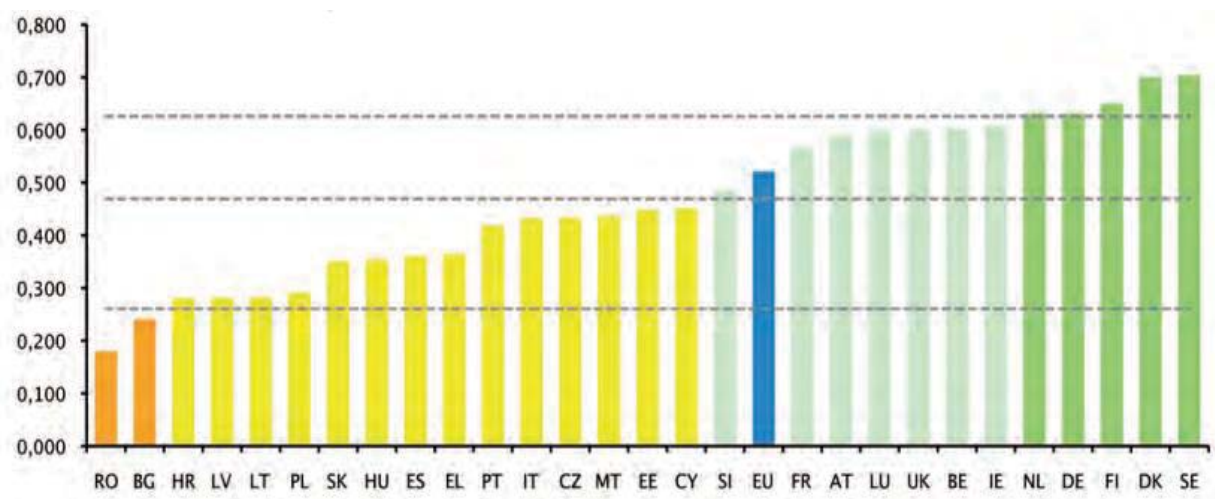

Figure 1. Innovation performance for EU's Member States Source: European Commission, 2016

The European Innovation Scoreboard places Romania and Bulgaria as the least innovator Member States in the European Union. One possible explanation for this situation could be the lack of interest towards investing in infrastructure or research. With a similar track record, both states have the needed geographical preconditions to implement the renewable energy strategy. But, taking into the 
consideration the fact that neither of these actors strive for development in the field of innovation, a valid question arises: how feasible is it for a country that does not invest in innovation to implement, and develop, the appropriate technology for efficient alternative energy?

Given the high importance of infrastructure in the development of a fully liberalized and integrated European energy market, 2016 has been the year when the European Commission had prepared a document consisting of 195 energy infrastructure projects that were to be advanced. Out of the 195 proposals, some concern interconnections, while others promote the mere appropriate development of alternative routes for energy distribution, as follows:

\section{Table no 4. Key development projects proposed for the European Union}

\begin{tabular}{|c|c|c|}
\hline No. & Outcome & Specific measures \\
\hline \multirow[t]{3}{*}{1} & \multirow[t]{3}{*}{$\begin{array}{l}\text { Priority Corridor Northern } \\
\text { Seas Offshore Grid - NSOG }\end{array}$} & $\begin{array}{l}\text { Interconnecting the United Kingdom and Belgium for } \\
\text { the first time }\end{array}$ \\
\hline & & $\begin{array}{l}\text { Increase capacity among Germany, the Netherlands } \\
\text { and Denmark }\end{array}$ \\
\hline & & $\begin{array}{l}\text { Increase transmission amplitude amid Ireland, France } \\
\text { and the United Kingdom }\end{array}$ \\
\hline \multirow[t]{5}{*}{2} & \multirow{5}{*}{$\begin{array}{l}\text { Priority Corridor North- } \\
\text { South Electricity } \\
\text { Interconnections in Western } \\
\text { Europe - NSI West } \\
\text { Electricity }\end{array}$} & $\begin{array}{l}\text { Internal line in Austria in order to upsurge the } \\
\text { capacity of the German - Austrian border }\end{array}$ \\
\hline & & Interconnecting Belgium and Germany \\
\hline & & $\begin{array}{l}\text { Integration of renewable energy and an increase in the } \\
\text { transmission capacity by developing a cluster corridor } \\
\text { North-South-West in Germany }\end{array}$ \\
\hline & & $\begin{array}{l}\text { Projects aimed to stimulate the usage of renewable } \\
\text { energy among Northern Ireland and Ireland }\end{array}$ \\
\hline & & Escalate the transmission capacity amidst Italy and \\
\hline
\end{tabular}




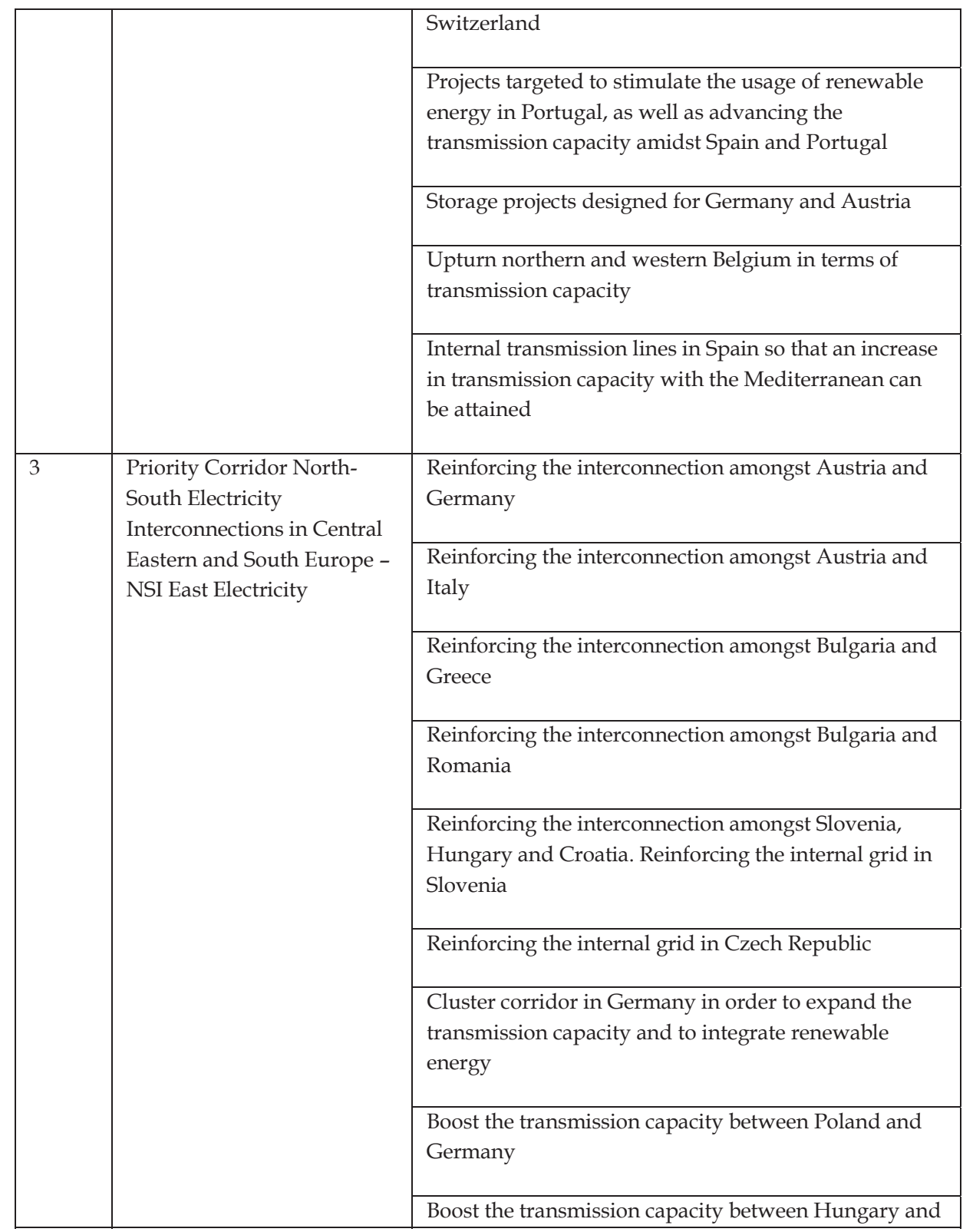




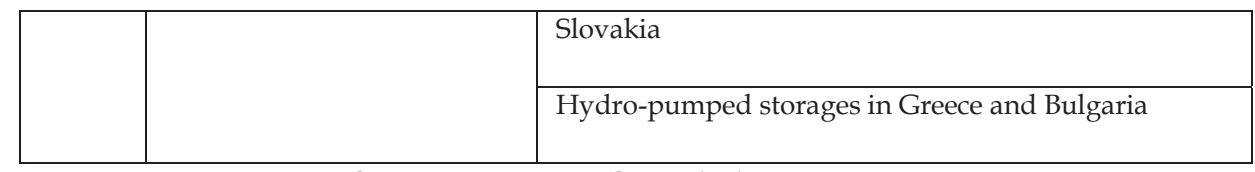

Source: European Commission 2016, p. 4

The above mentioned projects are a reflection for the capacity of innovation of each Member State, leading to two types of designs: interconnection amidst states and promoting the usage of renewable energy. The interconnection ventures are destined for states that are above the average of innovation capacity in Europe, as depicted in Figure 1, states such as Austria, Belgium and Germany. The same states appear to be of importance when promoting the usage of renewable resources in energy; in addition, Ireland, another strong innovator state, is taken into consideration for the increase of share of renewable energy resources in consumption. Even though Spain, Portugal, Slovakia and Hungary are considered to be below the average of innovation efforts in Europe, strong measures aimed to enforce the transmission capacity were introduced. Unlike the following states, Bulgaria and Romania, the least developed countries in terms of innovation, are not targeted for the usage of renewable energy, more as supported through efforts of interconnection, an action which, on the long run, ensure stability and more efficient transport routes; efficiency quantified in cost of transport, time, as well as technology that is being use in this sector. On the other hand, countries that produce too much green energy must be the key actors in preservation and efficient consumption strategies, so that the energy market could remain efficient even though the production surpasses the consumption capacity.

The EU's capacity of providing reliable long-term energy provisions can be questioned when taking into consideration the fact that most of the existing storage systems, in terms of electricity, have been designed with the sole purpose of storing overcapacity provided by nuclear and coal power stations (European Parliament 2015, 28). This is why, on the long run, a storage strategy would selfensure proper distribution, as well as a reliable resource for a needed action plan in case of scarce energy provisions. The development of technology and internal policies in terms of market regulation at European level can be translated in 
specific approaches towards dealing with long term energy resources, but not stable ones. For example, the share of renewable energy at the EU level depends on each state's capacity of providing a stable amount of finite product. Moreover, the differences in terms of innovation capacity and investment rate that characterize each state, lead to variable renewable energy resources.

\section{CONCLUSIONS}

In this paper I investigated the way in which the European energy framework decreases the gap between Member States (or why it fails to do so). By analysing both the strategies tailored for this sector, as well as the variables that directly influence the liberalization process, I was able to demonstrate that even though we are dealing with an ongoing process, certain Member States lack the necessary means of fully implementing the proposed framework. This is why disparities still occur in Member States such as Romania and Bulgaria, both being characterized by an inadequacy in terms of innovation activities. Moreover, the prices paid for electricity by the end-consumers in different Member States fluctuate, some of them being above the European average.

There is an urgent need for tailored measures that ensure the protection of poor energy consumers (or vulnerable ones), but, in the same time, the criteria used for identifying still needs amendments in accordance with economic and social factors that characterize each Member State. The answer to the question concerning to what extent can the liberalization process be considered an indepth one, as long as several disparities still arise at national level, is that at its current state, liberalization cannot be considered a fully implemented measure at European level; moreover, the presented disparities require further Action Plans and Directives to ensure fair prices and services for the end-consumer regardless of its residency. 


\section{ACKNOWLEDGEMENT}

Data used in this paper have been presented in the "Is the European Society a Vulnerable One? The Context of International Migrations" conference. This research was conducted through the "Competitivity and excellency in PhD research in Political Science, Administrative Science, Sociology and Communication Science" grant, POSDRU $187 / 1.5 /$ S/155589. Data concerning the Energy strategies and the evolution of the market have been gathered through the "Competitivity Inter-university cooperation for development of courses and master in the evaluation of programs and public policy Research Scholarship, POSDRU /18/1.2/G/28682" Competitivity grant. Data concerning the energy market evolution have been used in the article "Understanding the European Economic Environment: is the Energy Market Liberalization Policy a Vote for Development or a Vulnerability Waiting to Arise?" in Governance and Europeanization as a framework for Understanding the European Society, coordinator Ana Maria Costea et. al. , Tritonic, Bucharest, 2015.

\section{REFERENCES}

- $\quad$ ANRE,

Report

2009,

https:/ / www.google.ro/url?sa=t\&rct=j\&q=\&esrc=s\&source=web\&cd=1\&cad=rja\&uact= 8\&ved=0ahUKEwigqLGk443UAhXPbVAKHVjoA3YQFgglMAA\&url=http $\% 3 \mathrm{~A} \% 2 \mathrm{~F} \% 2 \mathrm{Fw}$ ww.anre.ro\%2Fdownload.php\%3Ff\%3DhA\%253D\%253D\%26t\%3Dvdeyut7dlcecrLbbvbY \%253D\&usg=AFQjCNFjz9CoGJECYhc7b_RUvQn7en3q7w accessed 22 May 2017

- ANRE, 2015, https:/ / www.google.ro/url?sa=t\&rct=j\&q=\&esrc=s\&source=web\&cd=3\&cad=rja\&uact= 8\&ved=0ahUKEwjtuvGu543UAhXMDZoKHboSDvsQFggxMAI\&url=http $\% 3 \mathrm{~A} \%$ 2F $\%$ 2Fw ww.anre.ro\%2Fdownload.php\%3Ff\%3Dgq2Big\%253D\%253D\%26t\%3Dvdeyut7dlcecrLbb vbY\%253D\&usg=AFQjCNGDXvdFjQUagvQ2wWrYjBuoJvt-BQ accessed 22 May 2017

- Commission of the European Communities, The Internal Energy Market, http:/ /aei.pitt.edu/4037/1/4037.pdf accessed 23 April 2017

- Commission of the European Communities, COMMUNICATION FROM THE COMMISSION Action Plan for Energy Efficiency: Realising the Potential, SEC(2006)1173, http:/ / eur-lex.europa.eu/legalcontent/EN/TXT/PDF/?uri=CELEX:52006DC0545\&from=EN accessed 5 April 2017

- $\quad$ European Commission, COMMUNICATION FROM THE COMMISSION TO THE ERUOPEAN PARLIAMENT, THE COUNCIL, THE EUROPEAN ECONOMIC AND SOCIAL COMMITTEE, THE COMMITTEE OF THE REGIONS AND THE EUROPEAN INVESTMENT BANK Clean Energy For All Europeans, Brussels, 2016, COM (2016) 860, 
http:/ / eur-lex.europa.eu/resource.html?uri=cellar:fa6ea15b-b7b0-11e6-9e3c01aa75ed71a1.0001.02/DOC_1\&format=PDF , accessed 27 April 2017

- $\quad$ European Commission, DIRECTIVE OF THE EUROPEAN PARLIAMENT AND OF THE COUNCIL amending Directive 2012/27/EU on energy efficiency, COM92016) 761, http://ec.europa.eu/energy/sites/ener/files/documents/1_en_act_part1_v16.pdf accessed 4 April 2017

- $\quad$ European Commission, REPORT FROM THE COMMISSION TO THE EUROPEAN PARLIAMENT, THE COUNCIL, THE EUROPEAN ECONOMIC AND SOCIAL COMMITTEE AND THE COMMITTEE OF THE REGIONS Energy prices and costs in Europe, SWD(2016) 420, http:/ /ec.europa.eu/energy/sites/ener/files/documents/com_2016_769.en_.pdf , accessed 27 April 2017

- European Commission, European Innovation Scoreboard, 2016, http:/ / ec.europa.eu/DocsRoom/documents/17822 accessed 3 April 2017

- $\quad$ European Parliament, Directorate-General for Internal Policies, Energy Storage: Which Market Designs and Regulatory Incentives Are Needed?, 2015, http:/ / www.europarl.europa.eu/RegData/etudes/STUD/2015/563469/IPOL_STU(2015 )563469_EN.pdf accessed 25 March 2017

- $\quad$ EUROSTAT, Electricity prices for domestic consumers - bi-annual data (from

2007

http:/ /appsso.eurostat.ec.europa.eu/nui/show.do?dataset=nrg_pc_204\&lang=en accessed 14 April 2017

- Journal of the European Union, 2003, Directive 2003/54/EC of the European Parliament and of the Council of 26 June 2003 concerning common rules for the internal market in electricity and repealing Directive 96/92/EC, http://eurlex.europa.eu/resource.html?uri=cellar:caeb5f68-61fd-4ea8-b3b5-

00e692b1013c.0004.02/DOC_1\&format=PDF accessed 14 April 2017

- Official Journal of the European Union, L19/1, 2016, COMMISSION DELEGATED REGULATION (EU) 2016/89 of 18 November 2015 amending Regulation (EU) No 347/2013 of the European Parliament and of the Council as regards the Union list of projects of common interest, http://eur-lex.europa.eu/legalcontent/EN/TXT/PDF/?uri=OJ:JOL_2016_019_R_0001\&from=EN accessed 2 April 2017

- Official Journal of the European Communities, No L 27/20, Directive 96/92/EC OF THE EUROPEAN PARLIAMENT AND OF THE COUNCIL of 19 December 1996 concerning common rules for the internal market in electricity, http://eurlex.europa.eu/legal-content/EN/TXT/PDF/?uri=CELEX:31996L0092\&from=EN accessed 14 April 2017

- Official Journal of the European Union, DIRECTIVE 2009/28/EC OF THE EUROPEAN PARLIAMENT AND OF THE COUNCIL of 23 April 2009 on the promotion of the use of energy from renewable sources and amending and subsequently repealing Directives 2001/77/EC and 2003/30/EC, L140/16, http://eur-lex.europa.eu/legalcontent/EN/TXT/PDF/?uri=CELEX:32009L0028\&from=EN accessed 28 March 2017 
- $\quad$ Official Journal of the European Communities, L 204/1, DIRECTIVE 98/30/EC OF THE EUROPEAN PARLIAMENT AND OF THE COUNCIL of 22 June 1998 concerning common rules for the internal market in natural gas, http://eurlex.europa.eu/legal-content/EN/TXT/PDF/?uri=CELEX:31998L0030\&from=EN accessed 14 April 2017

- Official Journal of the European Union, volume 50, 2007, Treaty of Lisbon, http:/ / eur-lex.europa.eu/legal-

content/EN/TXT/PDF/?uri=OJ:C:2007:306:FULL\&from=EN accessed 10 April 2017 